\title{
PENGEMBANGAN LEMBAR KERJA PESERTA DIDIK (LKPD) INDUSTRI KECIL KIMIA BERORIENTASI KEWIRAUSAHAAN UNTUK SMK
}

\author{
Artina Diniaty ${ }^{1)}$, Sri Atun ${ }^{2)}$ \\ Program Studi Pendidikan Sains PPs UNY ${ }^{1)}$, Universitas Negeri Yogyakarta ${ }^{2)}$ \\ art_3ds@yahoo.co.id ${ }^{1)}$, Atun_1210@yahoo.com ${ }^{2)}$
}

\begin{abstract}
Abstrak
Penelitian ini bertujuan untuk menghasilkan lembar kerja peserta didik (LKPD) industri kecil kimia berorientasi kewirausahaan, dan mengetahui kelayakan LKPD untuk pembelajaran. Penelitian ini merupakan penelitian pengembangan yang mengacu pada model pengembangan Borg \& Gall. Prosedur dalam penelitian pengembangan ini terdiri dari empat tahap, yaitu tahap pendahuluan. perencanaan, pengembangan, dan evaluasi produk. Evaluasi produk dilakukan oleh teman sejawat, ahli materi dan media, serta guru kimia untuk mendapatkan masukan dan penilaian mengenai kualitas LKPD. Instrumen pengumpulan data yang digunakan berupa lembar validasi produk. Hasil penelitian menunjukkan bahwa LKPD industri kecil kimia berorientasi kewirausahaan dengan kategori sangat baik, sehingga LKPD yang dikembangkan layak digunakan dalam pembelajaran.
\end{abstract}

Kata Kunci: pengembangan, LKPD, kewirausahaan

\section{DEVELOPING STUDENTS' WORKSHEET OF ENTREPRENEURSHIP-ORIENTED SMALL- SCALE CHEMICAL INDUSTRY}

\begin{abstract}
This study aims for developing students' worksheet of entrepreneurship-oriented small-scale chemical industry, and investigating the quality of entrepreneurship-oriented small-scale chemical industry that is appropriate to be implemented in learning. This study is classified to research and development which refers to Borg \& Gall development model. This research consists of four steps: which are introduction, planning, developing, and product evaluation. The product evaluation was conducted by peers, material and media experts, and chemistry teachers. The data collection instruments used validation sheet of the products. The results show that the developed products are in the form of students' worksheet of entrepreneurship-oriented small-scale chemical industry, and the result of the assessment by chemistry teachers shows the average assessment is a good category so that this worksheet is feasible to be used in learning.
\end{abstract}

Keywords: developing, students' worksheet, entrepreneurship 


\section{Pendahuluan}

Sekolah Menengah Kejuruan (SMK) merupakan lembaga pendidikan yang mengutamakan pengembangan kemampuan peserta didik untuk dapat bekerja dalam bidang tertentu, beradaptasi di lingkungan kerja, melihat peluang kerja dan mengembangkan diri. Kurikulum SMK menitikberatkan pada keterampilan yang bersifat praktis dan fungsional yang berisi aspek teori, mengarahkan pada pemberian bekal kecakapan atau keterampilan khusus, serta mempersiapkan kemampuan peserta didik untuk langsung memasuki dunia kerja. Oleh karena itu, SMK berperan dalam menyiapkan peserta didik agar siap bekerja, baik bekerja secara mandiri maupun mengisi lowongan pekerjaan yang ada (Utami dan Hudaniah, 2013, p.40).

SMK diharapkan bisa menghasilkan lulusan yang siap kerja, namun kenyataannya pengangguran terbuka paling banyak justru berasal dari lulusan SMK. Berdasarkan data Badan Pusat Statistik (BPS) bulan Agustus 2012 menunjukkan jumlah penganggur terbuka tercatat sebanyak 7,24 juta orang $(6,14 \%)$ dari total angkatan kerja berdasarkan pendidikan sebanyak 118,05 juta orang. Jumlah pengangguran terbuka lulusan SD ke bawah sebesar 3,64\%, SMP 7,76\%, SMA 9,60\%, SMK 9,87\%, Diploma 6,21\%, dan Sarjana 5,91\% (Badan Pusat Statistik, 2013: 54). Berdasarkan data tersebut menunjukkan bahwa lulusan SMK menduduki peringkat tertinggi. Faktor yang menyebabkan terjadinya pengangguran, di antaranya: (1) adanya kesenjangan antara supply and demand, jumlah pencari kerja lebih besar dari jumlah peluang kerja yang tersedia; (2) terjadinya kesenjangan antara kompetensi pencari kerja dengan kompetensi yang dibutuhkan oleh pasar kerja; (3) adanya lulusan yang tidak dapat berusaha secara mandiri karena tidak memiliki keterampilan atau life skills yang memadai; (4) terbatasnya kemampuan dalam mengolah sumber daya alam menjadi produk yang bernilai ekonomis sebagai sumber mata pencaharian; serta (5) mindset yang menginginkan untuk memilih profesi yang relatif tanpa resiko sebagai pegawai (Kemdiknas, 2010, p.1). Alternatif yang dapat ditempuh untuk mengatasi kondisi tersebut dengan cara mengandalkan kekuatan sendiri atau menjadi wirausaha, sehingga perlu untuk mengembangkan semangat kewirausahaan. Sejalan dengan ini, sejak tahun 2010, pendidikan kewirausahaan diwajibkan di seluruh SMK di Kota Yogyakarta. Lulusan SMK diha- rapkan tidak hanya sebagai pencari kerja, namun diarahkan sebagai pencipta lapangan pekerjaan. Kepala Bidang Pendidikan Menengah Dinas Pendidikan Kota Yogyakarta Suyono mengatakan, kurikulum kewirausahaan mulai diberlakukan sejak pertengahan tahun 2010 setelah revisi kurikulum kewirausahaan tahun 2009 dengan materi pembelajaran yang berbeda. Aplikasi mata pelajaran kewirausahaan disesuaikan dengan kebutuhan dan kultur sekolah. Sekolah harus merancang pembelajaran yang paling cocok untuk peserta didiknya (Kompas, 2010). Kondisi ini didukung dengan pencanangan Gerakan Nasional Kewirausahaan (GKN) oleh Presiden Susilo Bambang Yudhoyono pada bulan Februari 2011 dalam rangka meningkatkan pengembangan kewirausahaan di seluruh tanah air. GKN menginduksi generasi muda untuk memiliki minat menjadi wirausahawan (Aprilianty, 2012, p.312).

Kewirausahaan berasal dari istilah entrepeneurship yang sebenarnya berasal dari kata entrepreneur, artinya suatu kemampuan (ability) dalam berfikir kreatif dan berperilaku inovatif yang dijadikan dasar, sumber daya, tenaga penggerak tujuan, dan proses dalam menghadapi tantangan hidup (Wibowo, 2011, p.109). Kewirausahaan disamakan dengan entrepreneurship atau wirausaha yang diartikan berbeda-beda namun pada prinsipnya mempunyai maksud dan ruang lingkup yang sama. Kewirausahaan berasal dari kata wirausaha. Wirausaha berasal dari kata wira yang artinya berani, utama, maupun mulia. Kata usaha mengandung makna usaha secara terus menerus dalam mengelola sumber daya untuk menghasilkan barang dan jasa dalam rangka mendapatkan keuntungan (Nuryanti dan Mahri, 2010, p.808). Jadi kewirausahaan diartikan secara harfiah sebagai keberanian seseorang untuk melakukan kegiatan mengelola sumber daya untuk mendapatkan keuntungan.

Kewirausahaan merupakan gabungan dari kreativitas, inovasi dan keberanian dalam menghadapi resiko yang dilakukan dengan kerja keras untuk membentuk dan memelihara suatu usaha (Hakim, 2010, p.3). Kuratko \& Hodgetts, (2004, p.30) menyatakan "Entrepreneurship is a dynamic process of vision, change, and creation". It requires an application of energy and passion towards the creation and implementation of new ideas and creative solutions". Kewirausahaan juga dapat diartikan sebagai proses menciptakan sesuatu yang berharga dan berbeda melalui usaha yang disertai dengan keuangan, mental, risiko untuk mendapatkan keuntungan dan 
kepuasan (Hosseini dan Ahmadi, 2012, p.144). Kewirausahaan dapat juga digambarkan sebagai proses menyatukan dan menggabungkan ide-ide kreatif dan inovatif dengan keterampilan pengelolaan untuk menggabungkan orang, uang dan sumber daya dalam rangka memenuhi kebutuhan dan menciptakan kesejahteraan (Arogundade dan Bukola, 2011, p.26). Kewirausahaan merupakan kemampuan untuk melihat peluang dan mengambil peluang dengan memanfaatkan dan mengolah sumber daya yang ada untuk mendapatkan keuntungan.

Indikator, ciri, serta sifat kewirausahaan dari seorang wirausaha (Suryana, 2004, pp.1633) antara lain: (a) motif berprestasi tinggi, yaitu nilai sosial yang menekankan pada hasrat untuk mencapai yang terbaik guna mencapai kepuasan secara pribadi. Faktor dasarnya berupa kebutuhan yang harus dipenuhi; (b) selalu perspektif, artinya berorientasi ke masa depan, karena memiliki pandangan jauh ke masa depan, sehingga akan selalu berusaha untuk berkarya; (c) memiliki kreativitas tinggi, yaitu menciptakan sesuatu yang baru dengan mengkombinasikan sumber yang ada di sekitarnya, mengembangkan teknologi baru, mengembangkan cara baru untuk menghasilkan barang dan jasa baru yang lebih efisien; (d) memiliki perilaku inovasi tinggi, artinya mampu menerapkan kreativitas dalam rangka memecahkan persoalan hidup; (e) selalu komitmen dalam pekerjaannya, memiliki etos kerja dan tanggung jawab; (f) mandiri dan tidak ketergantungan; (g) berani menghadapi resiko, yaitu berani menghadapi kemungkinan terjadinya sesuatu yang tidak diduga maupun diinginkan; (h) selalu mencari peluang; (i) memiliki jiwa kepemimpinan; serta (j) memiliki kemampuan manajemen, artinya mampu merencanakan, mengelola usaha dan sumber daya yang ada.

Pendidikan yang berwawasan kewirausahaan merupakan pendidikan yang menerapkan prinsip dan metodologi ke arah pembentukan kecakapan hidup (life skills) pada peserta didiknya melalui kurikulum yang terintegrasi yang dikembangkan di sekolah (Wibowo, 2011, p.113). Gorman, Hanlon, \& King (1997, p.63) menyatakan "...most of the empirical studies surveyed indicated that entrepreneurship can be taught, or at least encouraged, by entrepreneurship education". Pendidikan kewirausahaan bertujuan untuk mempersiapkan peserta didik agar memiliki sikap kewirausahaan dan mampu mengembangkan seluruh potensi yang ada pada dirinya untuk menghadapi masa depan dengan segala permasalahan yang akan dihadapi (Kemdiknas, 2010, p.23). Kemampuan inilah yang kemudian dikenal dengan kecakapan hidup (life skills).

Life skills dilihat dari segi bahasa berasal dari dua kata, yaitu life dan skills. Life berarti hidup, sedangkan skills mengandung makna kecakapan, kepandaian, keterampilan, sehingga life skills secara bahasa diartikan sebagai kecakapan, kepandaian atau keterampilan hidup (Nurohman, 2006, p.62). Brolin (Depdiknas, 2007, p.5) menyatakan bahwa kecakapan hidup merupakan interaksi dari berbagai pengetahuan dan kecakapan, sehingga seseorang mampu hidup mandiri. Penjelasan mengenai kecakapan hidup juga diajukan oleh IOWA State University, yang tidak hanya diartikan sebagai kemampuan untuk melakukan sesuatu, tetapi kecakapan juga dimaknai sebagai kemampuan belajar untuk melakukan sesuatu secara lebih baik. (WHO, 1997, p.1) menjelaskan "Life skills are abilities for adaptive and positive behaviour that enable individuals to deal effectively with the demands and challenges of everyday life". Berdasarkan berbagai definisi mengenai kecakapan hidup, dapat dipahami bahwa kecakapan hidup merupakan kecakapan yang dimiliki seseorang untuk aktif dan kreatif dalam mengatasi berbagai persoalan dalam hidupnya.

Berdasarkan konsepnya, kecakapan hidup dapat dibagi menjadi dua jenis utama, yaitu kecakapan hidup generik (generic life skills/ $G L S$ ), dan kecakapan hidup spesifik (specific life skills/SLS) (Nuryanti dan Mahri, 2010, p.807; Depdiknas, 2007, p.6; Wiratno, 2008, pp.516518). Setiap jenis kecakapan dapat dibagi menjadi subkecakapan. Kecakapan hidup generik terdiri atas kecakapan personal (personal skill), dan kecakapan sosial (social skill). Kecakapan personal mencakup kecakapan dalam mengenal diri (self awareness skill) dan kecakapan berpikir (thinking skill). Kecakapan mengenal diri pada dasarnya merupakan penghayatan diri sebagai makhluk Tuhan Yang Maha Esa, sebagai anggota masyarakat dan warga negara, serta menyadari dan mensyukuri kelebihan dan kekurangan yang dimiliki sekaligus sebagai modal dalam meningkatkan dirinya sebagai individu yang bermanfaat bagi lingkungannya. Kecakapan berpikir berupa kecakapan dalam menggunakan rasio atau pikiran. Kecakapan ini meliputi kecakapan menggali informasi, mengolah informasi, dan mengambil keputusan secara cerdas, serta mampu memecahkan masalah dengan tepat. Kecakapan sosial mencakup kecakapan 
berkomunikasi (communication skill) dan kecakapan bekerja sama (collaboration skill). Kecakapan berkomunikasi dapat dilakukan melalui lisan maupun tulisan yang merupakan kecakapan dalam menyampaikan pesan secara lisan dan tertulis agar mudah dipahami oleh orang lain. Kecakapan bekerja sama merupakan kecakapan bekerja dalam suatu kelompok dengan adanya saling pengertian dan membantu antar sesama anggota untuk mencapai tujuan yang baik.

Kecakapan hidup spesifik berupa kecakapan untuk menghadapi pekerjaan atau keadaan tertentu. Kecakapan ini terdiri dari kecakapan akademik (academic skill) dan kecakapan vokasional (vocational skill). Kecakapan akademik terkait dengan bidang pekerjaan yang lebih memerlukan pemikiran atau kerja intelektual yang pada dasarnya merupakan pengembangan dari kecakapan berpikir secara umum, namun mengarah pada kegiatan yang bersifat keilmuan. Kecakapan ini mencakup antara lain kecakapan mengidentifikasi variabel, menjelaskan hubungan suatu fenomena tertentu, merumuskan hipotesis, serta merancang dan melaksanakan penelitian. Kecakapan vokasional atau kecakapan kejuruan merupakan kecakapan yang dikaitkan dengan bidang pekerjaan tertentu yang terdapat di masyarakat atau lingkungan peserta didik (Depdiknas, 2007, p.7; Nuryanti dan Mahri, 2010, p.807). Peserta didik yang memiliki life skills diharapkan berkompeten, terampil serta siap bersaing dalam pekerjaannya.

Masalah yang terjadi selama ini, program kewirausahaan yang diajarkan di SMK belum mampu menghasilkan peserta didik yang memiliki sikap dan minat wirausaha serta keca-kapan hidup, sehingga banyak lulusan SMK yang tidak mampu membuka lapangan pekerja-an sendiri (Hakim, 2010, p.2). Banyak pula peserta didik yang bercita-cita untuk bekerja di perusahaan maupun pada instansi pemerintah. Berdasarkan hasil wawancara yang dilakukan terhadap guru kimia sekaligus wakil kepala urusan kurikulum SMK N 1 Panjatan Kulon Progo Yogyakarta, diketahui bahwa $40 \%$ lulus-annya lebih tertarik untuk bekerja, serta $40 \%$ melanjutkan ke perguruan tinggi. Kondisi ini menunjukkan bahwa minat peserta didik untuk menciptakan lapangan pekerjaan atau menjadi seorang wirausaha masih kurang. Oleh karena itu, perlu upaya untuk meningkatkan minat wirausaha peserta didik.

Guntoro (Anwar, Supardi, dan Sugiharto, 2012, p.42) mendefinisikan minat sebagai kesadaran seseorang yang dapat menimbulkan adanya keinginan. Minat pada dasarnya merupakan penerimaan suatu hubungan antara diri sendiri dengan sesuatu di luar dirinya (Adeline, 2011, p.3). Minat merupakan ketertarikan dan keinginan pada diri seseorang yang mengarahkan pada suatu pilihan tertentu.

Minat wirausaha merupakan aspek psikis yang mendorong perilaku wirausaha (Khoiri, 2011, p.86). Bird (Fitriani, Harnanik, Kusumantoro, 2012, p.1; Zampetakis et al., 2011, p.190) menyatakan bahwa minat wirausaha mengacu pada keadaan pikiran yang sadar yang mengarahkan perhatian seseorang untuk memenuhi tujuan dari penciptaan usaha. Sehubungan dengan itu minat wirausaha merupakan keinginan yang ada pada diri individu untuk dapat berwirausaha.

Kurikulum Tingkat Satuan Pendidikan (KTSP) untuk SMK berisi mata pelajaran kejuruan yang terdiri atas beberapa mata pelajaran yang bertujuan untuk menunjang pembentukan kompetensi kejuruan dan pengembangan kemampuan menyesuaikan diri dalam bidang keahliannya. Selain itu, terdapat mata pelajaran muatan lokal. Muatan lokal merupakan kegiatan kurikuler untuk mengembangkan kompetensi yang disesuaikan dengan ciri khas, potensi daerah, dan prospek pengembangan daerah termasuk keunggulan daerah. Substansi muatan lokal ditentukan oleh satuan pendidikan sesuai dengan program keahlian yang diselenggarakan (Sudira, 2006, p.24). SMK N 1 Panjatan merupakan SMK dengan program keahlian kimia industri, kimia analisis, dan kimia farmasi. Muatan lokal di SMK N 1 Panjatan, yaitu industri kecil kimia. Industri kecil kimia ini disesuaikan dengan potensi daerah dan program keahlian yang ada di sekolah. Industri kecil kimia yang ada di SMK N 1 Panjatan selama ini terdiri dari proses pembuatan Virgin Coconut Oil (VCO), pembuatan nata de coco, serta pembuatan aneka manisan dari buah. Untuk itu industri kecil kimia dapat diarahkan untuk menunjang pembelajaran kewirausahaan yang ada di SMK. Industri kecil kimia yang dilaksanakan belum sepenuhnya berhasil menunjang pembelajaran kewirausahaan. Kondisi ini disebabkan karena dipengaruhi oleh waktu, alat, dan media pembelajaran. Waktu yang digunakan untuk industri kecil masih kurang, karena hanya cukup untuk proses produksi saja, bahkan terkadang mengambil jam pelajaran di luar jam sekolah, sehingga peserta didik tidak sampai pada kegiatan berlatih melakukan promosi hasil produksinya. Alat yang digunakan untuk produksi juga belum lengkap mengingat mahalnya biaya pengadaan 
alat. Media pembelajaran yang digunakan salah satunya berupa jobsheet. Jobsheet ini hanya berisi teori singkat, alat dan bahan yang digunakan dalam pembuatan produk, serta prosedur dalam pembuatan produk, sehingga masih sederhana dan hanya berbentuk lembaran, belum berorientasi kewirausahaan yang sejalan dengan adanya pendidikan kewirausahaan yang diberlakukan di SMK.

Media pembelajaran memiliki peran penting di dalam proses pembelajaran karena digunakan untuk menyampaikan pesan (informasi) dalam kegiatan pembelajaran. Oleh karena itu, perlu disusun dan dikembangkan LKPD industri kecil kimia berorientasi kewira-usahaan. LKPD yang dikembangkan terdiri dari cover bagian depan dan belakang, kata pengantar, daftar isi, isi (zat warna dari kulit manggis, permen buah manggis, teh kulit manggis, sabun lidah buaya, dan pasta gigi dari cangkang kerang yang dilengkapi dengan kisah sukses orang dalam berwirausaha), contoh analisis usaha, format laporan, dan daftar pustaka.

LKPD berupa lembaran yang bertujuan untuk memacu dan membantu peserta didik melakukan kegiatan belajar dalam rangka menguasai pemahaman, keterampilan, dan atau sikap (Devi, Sofiraeni, dan Khairuddin, 2009, p.32). Penggunaan lembar kerja dapat membantu mengarahkan pembelajaran agar lebih efisien dan efektif (USAID DBE3, 2009, p.25). LKPD selain sebagai media pembelajaran juga mempunyai fungsi lain, yaitu: (1) merupakan alternatif bagi guru untuk mengarahkan pengajaran atau memperkenalkan kegiatan sebagai kegiatan pembelajaran; (2) membantu peserta didik untuk lebih aktif dalam proses pembelajaran; (3) dapat membangkitkan minat peserta didik jika LKPD disusun secara rapi, sistematis mudah dipahami oleh peserta didik, sehingga mudah menarik perhatian peserta didik; (4) dapat menumbuhkan kepercayaan pada diri peserta didik dan meningkatkan motivasi belajar dan rasa ingin tahu; serta (5) dapat meningkatkan kemampuan peserta didik dalam memecahkan masalah (Widjajanti, 2008, pp.1-2).

Dua bentuk LKPD untuk pembelajaran, yaitu LKPD untuk eksperimen dan LKPD noneksperimen atau lembar kerja diskusi. LKPD untuk eksperimen berupa lembar kerja yang memuat petunjuk praktikum. Sistematika LKPD secara umum terdiri dari (1) judul; (2) pengantar, uraian singkat yang mengetengahkan bahan pelajaran (berupa konsep) yang dicakup dalam kegiatan praktek; (3) tujuan, memuat tujuan yang berkaitan dengan permasalahan yang diungkapkan di pengantar; (4) alat dan bahan, memuat alat dan bahan yang diperlukan; (5) langkah kerja, merupakan instruksi untuk melakukan kegiatan. Langkah kerja ini dibuat secara sistematis untuk mempermudah peserta didik dalam melakukan kegiatan praktek. Apabila diperlukan, dapat menggunakan nomor urut dan menambah sketsa gambar; (6) tabel pengamatan, dapat berupa tabel data untuk mencatat data hasil pengamatan yang diperoleh dari kegiatan praktek; (7) pertanyaan, berupa pertanyaan yang jawabannya dapat membantu peserta didik untuk mendapatkan konsep yang dikembangkan atau untuk mendapatkan kesimpulan. LKPD noneksperimen berupa lembar kegiatan yang memuat teks yang menuntun peserta didik melakukan kegiatan diskusi mengenai materi pembelajaran (Devi, Sofiraeni, dan Khairuddin, 2009, pp.3233).

Faktor yang perlu diperhatikan dalam pembuatan LKPD yaitu (Devi, Sofiraeni, dan Khairuddin, 2009, pp.36-37): pertama, dari segi penyajian: (1) judul LKPD sesuai dengan materinya, (2) materi sesuai dengan perkembangan peserta didik, (3) materi disajikan secara sistematis dan logis, (4) materi disajikan secara sederhana dan jelas, serta (5) menunjang keterlibatan serta kemauan peserta didik untuk aktif.

Kedua, dari segi tampilan: (1) penyajian sederhana, jelas, dan mudah dipahami, (2) gambar dan grafik sesuai dengan konsepnya, (3) tata letak, gambar, tabel, dan pertanyaan harus tepat, (4) judul, keterangan, dan instruksi harus jelas, serta (5) mengembangkan minat dan mengajak peserta didik untuk berpikir.

LKPD harus memenuhi persyaratan, yaitu syarat didaktik, syarat konstruksi, dan syarat teknik (Rohaeti, Widjajanti, dan Padmaningrum, 2009, p.3). Syarat didaktik mengatur mengenai penggunaan LKPD yang bersifat universal yang dapat digunakan dengan baik oleh seluruh peserta didik. LKPD diharapkan mengutamakan pada pengembangan kemampuan komunikasi sosial, emosional, moral, dan estetika, serta mengajak peserta didik untuk aktif dalam proses pembelajaran. Syarat konstruksi berhubungan dengan penggunaan bahasa, susunan kalimat, kosa kata, tingkat kesukaran, dan kejelasan LKPD. Syarat teknis menekankan pada penyajian LKPD yang meliputi tulisan, gambar dan penampilan.

Penelitian pengembangan bertujuan untuk mengembangkan pengetahuan, teori pendidikan yang sudah ada, atau menghasilkan suatu produk di bidang pendidikan. Secara khusus penelitian 
pengembangan bertujuan untuk mengembangkan dan menguji produk yang dihasilkan. Penelitian pengembangan didasari pada analisis kebutuhan dan dapat menguji keefektifan produk yang dihasilkan agar dapat berfungsi di masyarakat luas (Sugiyono, 2007, p.297). Borg \& Gall (1983, p.772) menyatakan bahwa pendekatan penelitian dan pengembangan merupakan penelitian yang berorientasi untuk mengembangkan dan memvalidasi produk. Produk yang dihasilkan dalam penelitian pengembangan antara lain materi pelatihan guru, materi belajar untuk siswa, media pembelajaran untuk memudahkan belajar, metode pembelajaran, serta model pembelajaran.

Tujuan penelitian ini, yaitu: (1) mengembangkan LKPD industri kecil kimia berorientasi kewirausahaan, dan (2) menilai kualitas LKPD berdasarkan aspek isi, bahasa, dan penampilan.

Penelitian yang relevan dengan penelitian ini antara lain yang dilakukan oleh Fu'adi, Eko, dan Murdani (2009, pp.92-98) di SMK N 1 Adiwerna Kabupaten Tegal tahun ajaran 2008/ 2009 pada kelas XII teknik otomotif 2 dan teknik otomotif 3 . Hasil penelitian menunjukkan bahwa terdapat hubungan yang signifikan antara minat berwirausaha dengan prestasi praktik industri peserta didik kelas XII Teknik Otomotif SMK N 1 Adiwerna. Penelitian yang dilakukan oleh Kusuma dan Siadi (2010, pp.544-551) pada mahasiswa semester II kelas B Program Studi Pendidikan Kimia Jurusan Kimia FMIPA Unnes menunjukkan bahwa hasil belajar dan life skills mahasiswa dapat meningkat melalui penerapan bahan ajar berorientasi Chemo-entrepreneurship (CEP).

Penelitian yang dilakukan oleh Khoiri (2011, pp.84-88) pada siswa kelas X SMA 1 Demak tahun ajaran 2009/2010 menunjukkan bahwa penggunaan perangkat pembelajaran fisika berbasis life skills dapat meningkatkan minat kewirausahaan peserta didik serta terdapat hubungan yang signifikan antara life skills dan minat wirausaha peserta didik. Penelitian yang dilakukan oleh Anwar, Supardi, dan Sugiharto (2012, pp.38-44) pada siswa MA Al Irsyad Gajah Demak yang menujukkan bahwa perangkat pembelajaran biologi dengan pendekatan bioentrepreneurship dapat meningkatkan keterampilan proses dan minat berwirausaha peserta didik.

\section{METODE}

\section{Jenis Penelitian}

Penelitian ini merupakan penelitian pengembangan LKPD industri kecil kimia berorientasi kewirausahaan yang mengadaptasi dari model pengembangan Borg \& Gall (1983, p.775) yang meliputi sepuluh tahapan, yaitu penelitian dan pengumpulan informasi (research and information collecting), perencanaan (planning), pengembangan produk awal (develop preliminary form of product), uji coba lapangan awal (preliminary field testing), revisi produk hasil uji coba awal (main product revision), uji coba lapangan (main field testing), revisi produk hasil uji coba lapangan (operational product revision), uji coba pelaksanaan lapangan (operational field testing), revisi produk akhir (final product revision), diseminasi dan implementasi (dissemination and implementation).

Penelitian pengembangan LKPD industri kecil kimia berorientasi kewirausahaan ini terdiri dari empat tahapan, yaitu tahap studi pendahuluan, perencanaan, pengembangan produk, dan evaluasi produk.

\section{Prosedur Pengembangan}

Pengembangan LKPD mengikuti prosedur seperti yang ditunjukkan pada Gambar 1 .

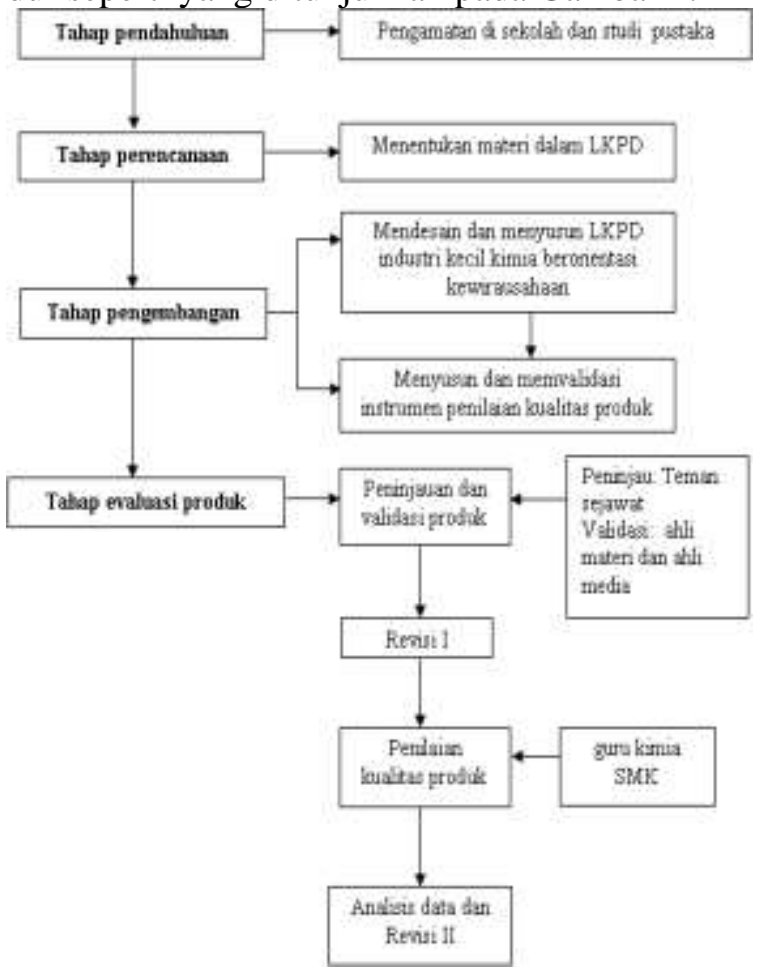

Gambar 1. Prosedur Penelitian Pengembangan LKPD Industri Kecil Kimia Berorientasi Kewirausahaan 
Tahap pendahuluan meliputi dua tahap, yaitu menganalisis kondisi lapangan untuk menemukan masalah yang terjadi dan melakukan studi pustaka yang relevan dengan penelitian yang dilakukan. Tahap perencanaan yang dilakukan di antaranya menentukan materi dalam LKPD yang dikembangkan. Tahap pengembangan meliputi tahapan, yaitu: (1) menentukan desain LKPD industri kecil kimia berorientasi kewirausahaan, (2) menyusun LKPD industri kecil kimia berorientasi kewirausahaan sesuai dengan rancangan, serta (3) menyusun dan memvalidasi instrumen yang digunakan untuk menilai LKPD industri kecil kimia berorientasi kewirausahaan. Tahap evaluasi produk meliputi tahapan, yaitu: (1) melakukan validasi LKPD industri kecil kimia berorientasi kewirausahaan oleh ahli materi dan ahli media untuk memperoleh masukan, (2) melakukan revisi terhadap LKPD industri kecil kimia berorientasi kewirausahaan berdasarkan masukan dari teman sejawat, ahli materi dan ahli media, (3) melakukan penilaian kualitas LKPD industri kecil kimia berorientasi kewirausahaan oleh guru kimia SMK, (4) melakukan revisi LKPD industri kecil kimia berorientasi kewirausahaan berdasarkan masukan guru kimia SMK, serta (5) melakukan analisis data penelitian.

\section{Instrumen, dan Teknik Pengumpulan Data}

Instrumen yang digunakan dalam penelitian ini berupa lembar validasi. Aspek penilaian LKPD meliputi tiga aspek, yaitu aspek isi, bahasa, dan penampilan yang masing-masing dijabarkan ke dalam subaspek yang masih dijabarkan lagi ke dalam indikator (Rohaeti dan Widjajanti, 2012, pp.4-6). Kriteria kualitas LKPD meliputi SB (sangat baik), B (baik), C (cukup), K (kurang), dan SK (sangat kurang). Secara garis besar instrumen penilaian yang mencakup aspek dan subaspek penilaian disajikan pada Tabel 1.

Tabel 1. Kisi-kisi Instrumen Penilaian Kualitas LKPD

\begin{tabular}{|c|c|c|}
\hline Aspek & Sub Aspek & $\begin{array}{c}\text { Jumlah } \\
\text { Indikator }\end{array}$ \\
\hline \multirow{3}{*}{ Isi } & $\begin{array}{c}\text { Pendekatan } \\
\text { Pengembangan }\end{array}$ & 4 \\
\hline & $\begin{array}{c}\text { Kebenaran dan } \\
\text { Kesesuaian Konsep }\end{array}$ & 4 \\
\hline & Kegiatan Peserta Didik & 4 \\
\hline \multirow{2}{*}{ Bahasa } & Kejelasan kalimat & 2 \\
\hline & Kebahasaan & 3 \\
\hline Penampilan & Tampilan LKPD & 4 \\
\hline
\end{tabular}

Subaspek pendekatan pengembangan meliputi: (1) penekanan pada pengembangan kecakapan hidup peserta didik; (2) penekanan pada pengembangan minat wirausaha peserta didik; (3) penekanan pada peningkatan keaktifan peserta didik dalam pembelajaran; serta (4) penekanan pada hubungan antara ilmu pengetahuan, teknologi, dan kehidupan.

Subaspek kebenaran dan kesesuaian konsep meliputi: (1) kesesuaian konsep dengan teori yang dikemukakan ahli kimia, (2) kesesuaian antara materi dengan kemampuan peserta didik, (3) kesesuaian antara materi dengan perkembangan ilmu, serta (4) hubungan konsep dengan kehidupan sehari-hari.

Subaspek kegiatan peserta didik meliputi: (1) hubungan kegiatan peserta didik dengan pengalaman langsung, (2) kesesuaian kegiatan peserta didik dengan materi pembelajaran, (3) keterlaksanaan kegiatan pembuatan produk, serta (4) keterlaksanaan kegiatan diskusi dan presentasi rencana usaha.

Subaspek kejelasan kalimat meliputi: (1) hubungan antara kalimat dengan makna, serta (2) hubungan antara kalimat dengan pemahaman peserta didik. Untuk subaspek kebahasaan meliputi: (1) kebakuan bahasa yang digunakan, (2) ketepatan ejaan, dan (3) ketepatan penggunaan istilah. Subaspek tampilan LKPD meliputi: (1) cetakan gambar dan tulisan, (2) penggunaan jenis huruf, (3) penggunaan ukuran huruf, serta (4) kesesuaian gambar dengan materi.

Data kualitas produk disajikan dalam bentuk tabel skor kualitas LPKD dan uraian saran. Uraian saran dirangkum untuk dijadikan landasan dalam melakukan revisi terhadap LKPD yang dikembangkan.

\section{Teknik Analisis Data}

Penelitian ini menggunakan analisis data deskriptif dengan langkah meliputi: (1) pengubahan data kualitatif yang diperoleh dari penilaian oleh tiga guru menjadi data kuantitatif dengan ketentuan seperti pada Tabel 2; serta (2) menghitung skor total rata-rata dari setiap subaspek, aspek, dan keseluruhan butir penilaian yang tersedia dalam instrumen penilaian menggunakan rumus :

$\bar{X}=\frac{\sum X}{n}$

Keterangan:

$\bar{X}=$ Skor rata-rata

$\sum X=$ Jumlah skor 
$\mathrm{N}=$ Jumlah responden

Tabel 2. Aturan Pemberian Skor

\begin{tabular}{cc}
\hline Kategori & Skor \\
\hline SB (Sangat Baik) & 5 \\
B (Baik) & 4 \\
C (Cukup) & 3 \\
K (Kurang) & 2 \\
SK (Sangat Kurang) & 1 \\
\hline
\end{tabular}

(3) mengubah skor rata-rata menjadi nilai kualitatif sesuai dengan kriteria kategori penilaian seperti pada Tabel 3 (Azwar, 1996, p.163).

Tabel 3. Kriteria Kategori Penilaian

\begin{tabular}{ccc}
\hline No & Rentang Skor & Kategori \\
\hline 1. & $\mathrm{M}+1,8 \mathrm{SB}<\bar{X}$ & Sangat baik \\
2. & $\mathrm{M}+0,6 \mathrm{SB}<\bar{X} \leq \mathrm{M}+1,8 \mathrm{SB}$ & Baik \\
3. & $\mathrm{M}-0,6 \mathrm{SB}<\bar{X} \leq \mathrm{M}+0,6 \mathrm{SB}$ & Cukup \\
4. & $\mathrm{M}-1,8 \mathrm{SB}<\bar{X} \leq \mathrm{M}-0,6 \mathrm{SB}$ & Kurang \\
5. & $\bar{X} \leq \mathrm{M}-1,8 \mathrm{SB}$ & Sangat \\
\end{tabular}

Keterangan:

$\mathrm{M}$ = Rata-rata

$=\frac{1}{2}($ skor maksimal + skor minimal $)$

$\mathrm{SB}=$ Simpangan baku

$=\frac{1}{2} \times \frac{1}{3}($ skor maksimal - skor minimal $)$

Skor maksimal $=\sum$ butir kriteria $\times$ skor tertinggi

Skor minimal $=\sum$ butir kriteria $\times$ skor terendah

Nilai kualitatif menunjukkan kualitas LKPD yang telah dikembangkan. LKPD industri kecil kimia berorientasi kewirausahaan layak untuk digunakan apabila hasil penilaian secara keseluruhan memberikan nilai minimal dengan kategori baik.

\section{HASIL DAN PEMBAHASAN}

Hasil penelitian pengembangan ini berupa tersusunnya LKPD industri kecil kimia berorientasi kewirausahaan yang terdiri dari bagian cover (depan dan belakang), kata pengantar, daftar isi, isi (pembuatan zat warna dari kulit manggis, pembuatan permen buah manggis, pembuatan teh dari kulit manggis, pembuatan sabun, dan pembuatan pasta gigi dari cangkang kerang), contoh analisis usaha, format laporan, dan daftar pustaka. Secara rinci isi dari LKPD dapat dilihat pada Tabel 4.
Tabel 4. Daftar Judul LKPD

\begin{tabular}{|c|c|c|}
\hline No & $\begin{array}{c}\text { Isi } \\
\text { (judul) }\end{array}$ & Sub judul \\
\hline 1 & $\begin{array}{l}\text { Zat warna } \\
\text { dari kulit } \\
\text { manggis }\end{array}$ & $\begin{array}{l}\text { Mengenal buah manggis } \\
\text { Pembuatan zat warna dari kulit } \\
\text { manggis dan peluang usaha zat } \\
\text { warna dari kulit manggis }\end{array}$ \\
\hline 2 & $\begin{array}{l}\text { Permen } \\
\text { Buah } \\
\text { Manggis }\end{array}$ & $\begin{array}{l}\text { Permen } \\
\text { Pembuatan permen buah manggis } \\
\text { dan peluang usaha permen buah } \\
\text { manggis } \\
\text { Usaha permen tradisional yang } \\
\text { beromzet jutaan dan menjadi } \\
\text { konglomerat berkat permen karet }\end{array}$ \\
\hline 3 & $\begin{array}{l}\text { Teh Kulit } \\
\text { Manggis }\end{array}$ & $\begin{array}{l}\text { Teh } \\
\text { Pembuatan teh kulit manggis dan } \\
\text { peluang usaha teh kulit manggis } \\
\text { Kisah Sukses Usaha Teh: (a) kisah } \\
\text { sukses pengusaha berusia } 18 \\
\text { tahun, (b) putra Wilda: dari sopir } \\
\text { angkot jadi raja teh }\end{array}$ \\
\hline 4 & $\begin{array}{l}\text { Sabun } \\
\text { Lidah } \\
\text { Buaya }\end{array}$ & $\begin{array}{l}\text { Sekilas tentang Sabun } \\
\text { Pembuatan sabun lidah buaya dan } \\
\text { peluang usaha sabun lidah buaya } \\
\text { Kisah Sukses Usaha Sabun: (a) } \\
\text { Wiyana Dewi, sukses dengan } \\
\text { bisnis sabun, (b) harumnya omzet } \\
\text { sabun susu }\end{array}$ \\
\hline 5 & $\begin{array}{l}\text { Pasta Gigi } \\
\text { dari } \\
\text { Cangkang } \\
\text { Kerang }\end{array}$ & $\begin{array}{l}\text { Sekilas tentang Pasta Gigi } \\
\text { Pembuatan pasta gigi dari } \\
\text { cangkang kerang dan peluang } \\
\text { usaha pasta gigi dari cangkang } \\
\text { kerang }\end{array}$ \\
\hline
\end{tabular}

LKPD yang disusun berukuran B5. Produk tersebut telah ditinjau oleh teman sejawat, serta telah divalidasi oleh ahli materi dan media. Berdasarkan hasil penilaian yang diperoleh dari tiga guru kimia disajikan hasilnya dalam Tabel 5 .

Tabel 5. Hasil Penilaian Kualitas LKPD Industri Kecil Kimia Berorientasi Kewirausahaan

\begin{tabular}{|c|c|c|c|c|}
\hline Aspek & Subaspek & $\begin{array}{l}\text { Skor } \\
\text { Rerata }\end{array}$ & $\begin{array}{c}\text { Skor } \\
\text { Rerata } \\
\text { Max } \\
\end{array}$ & Kategori \\
\hline \multirow{3}{*}{ A } & $\begin{array}{l}\text { Pendekatan } \\
\text { Pengembangan }\end{array}$ & 18,33 & 20 & $\begin{array}{l}\text { Sangat } \\
\text { Baik }\end{array}$ \\
\hline & $\begin{array}{l}\text { Kebenaran dan } \\
\text { Kesesuaian } \\
\text { Konsep }\end{array}$ & 17,67 & 20 & $\begin{array}{l}\text { Sangat } \\
\text { Baik }\end{array}$ \\
\hline & $\begin{array}{l}\text { Kegiatan } \\
\text { Peserta Didik }\end{array}$ & 18 & 20 & $\begin{array}{l}\text { Sangat } \\
\text { Baik }\end{array}$ \\
\hline \multirow{2}{*}{ B } & $\begin{array}{l}\text { Kejelasan } \\
\text { Kalimat }\end{array}$ & 8,67 & 10 & $\begin{array}{l}\text { Sangat } \\
\text { Baik }\end{array}$ \\
\hline & Kebahasaan & 13 & 15 & $\begin{array}{l}\text { Sangat } \\
\text { Baik }\end{array}$ \\
\hline $\mathrm{C}$ & $\begin{array}{l}\text { Tampilan } \\
\text { LKPD }\end{array}$ & 17,33 & 20 & $\begin{array}{l}\text { Sangat } \\
\text { Baik }\end{array}$ \\
\hline
\end{tabular}


Berdasarkan hasil penilaian untuk tiap subaspek dan aspek diperoleh bahwa untuk semua subaspek mendapatkan kategori sangat baik dan semua aspek juga mendapatkan kategori sangat baik, sehingga secara keseluruhan mendapatkan kategori sangat baik. Hasil penilaian kualitas untuk setiap subaspek disajikan dalam bentuk diagram pada Gambar 2 .

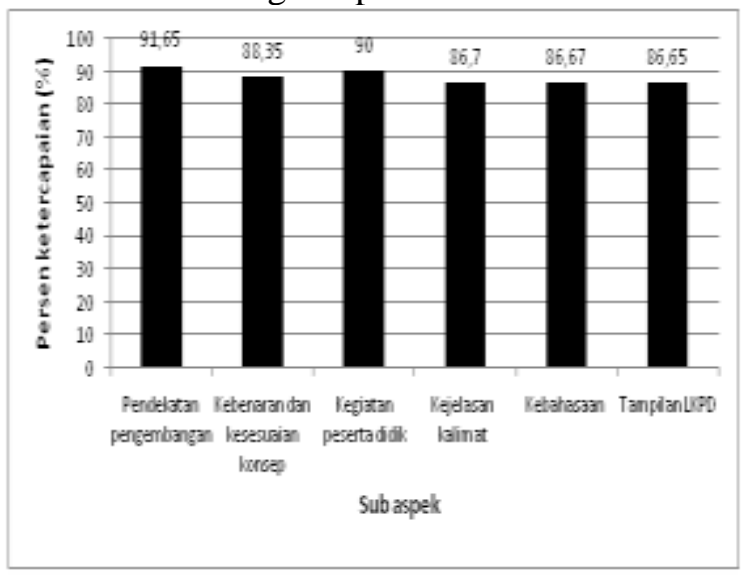

Gambar 2. Diagram Penilaian Kualitas LKPD Tiap Subaspek

Gambar 2 menunjukkan bahwa subaspek pendekatan pengembangan merupakan subaspek yang mendapatkan nilai tertinggi dibandingkan dengan subaspek lainnya dengan persen ketercapaian $91,65 \%$, yang diikuti dengan subaspek kegiatan peserta didik dengan persen ketercapaian $90 \%$. LKPD yang disusun telah menekankan pada pengembangan life skills, minat wirausaha serta dapat mengajak peserta didik untuk aktif dalam pembelajaran. Semua kegiatan yang ada dalam LKPD dapat memberikan pengalaman langsung pada peserta didik. Skor terendah diperoleh pada subaspek tampilan LKPD dengan persen ketercapaian $86,65 \%$. Hasil ini disebabkan oleh penilaian guru yang menganggap bahwa ukuran huruf (font) yang digunakan dalam LKPD terlalu besar berdasarkan masukan yang diberikan oleh guru. Font yang digunakan dalam LKPD menggunakan font standar, yaitu times new roman 12, kecuali untuk judul dan subjudul. Apabila font yang digunakan diperkecil, dikhawatirkan akan sulit untuk dibaca.

Hasil penilaian kualitas untuk setiap aspek disajikan pada Gambar 3.

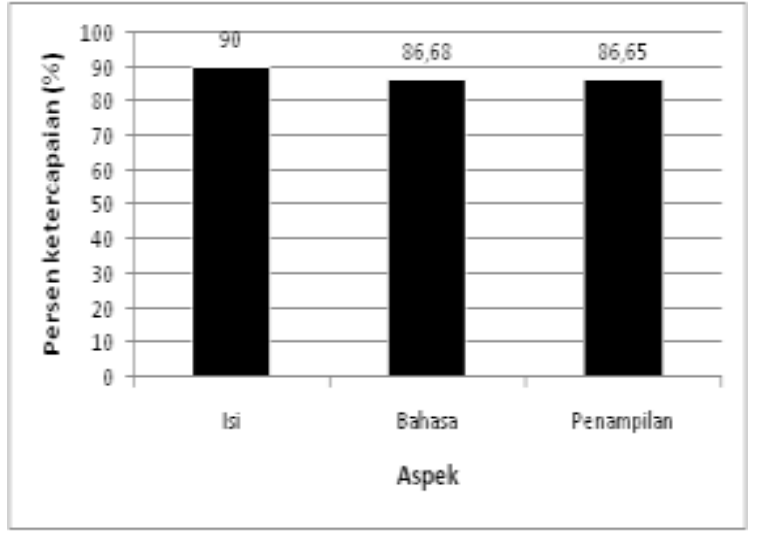

Gambar 3. Diagram Penilaian Kualitas LKPD Tiap Aspek

Gambar 3 menunjukkan bahwa aspek isi mendapatkan nilai tertinggi dibandingkan dengan aspek yang lainnya dengan persen ketercapaian sebesar 90\%. Secara keseluruhan LKPD mendapatkan penilaian dengan kategori sangat baik, sehingga produk hasil pengembangan berupa LKPD industri kecil kimia berorientasi kewirausahaan layak untuk digunakan dalam pembelajaran. LKPD yang dihasilkan memiliki kelebihan dalam memberi-kan pengalaman langsung pada peserta didik, mengajak peserta didik untuk aktif dalam pembelajaran serta menekankan pada pengembangan life skills dan minat wirausaha.

\section{SIMPULAN DAN SARAN}

\section{Simpulan}

Berdasarkan hasil penelitian, dapat disimpulkan bahwa: (1) produk yang dihasilkan berupa LKPD industri kecil kimia berorientasi kewirausahaan, serta (2) hasil penilaian oleh guru kimia menunjukkan bahwa rata-rata penilaian masuk kategori sangat baik, sehingga LKPD industri kecil kimia berorientasi kewirausahaan layak digunakan dalam pembelajaran.

\section{Saran}

LKPD berorientasi kewirausahaan hendaknya digunakan dalam pembelajaran dan diuji cobakan pada peserta didik untuk mengetahui pengaruh penggunaan LKPD tersebut terhadap life skills dan minat wirausaha peserta didik.

\section{DAFTAR PUSTAKA}

Adeline. (2011). Faktor-faktor yang mempengaruhi minat berwirausaha budidaya lele sangkuriang. Jurnal Ekonomi Manajemen, pp.1-9. 
Anwar, M., Supardi, \& Sugiharto. (2012). Pengembangan perangkat pembelajaran biologi dengan pendekatan bioenterpreneurship untuk meningkatkan keterampilan proses ilmiah dan minat berwirausaha siswa. Innovative Journal and Curriculum and Educational Technology, 1, 1, pp.38-44.

Aprilianty, E. (2012). Pengaruh kepribadian wirausaha, pengetahuan kewirausahaan, dan lingkungan terhadap minat berwirausaha siswa SMK. Jurnal Pendidikan Vokasi, 2, 3, pp.311-324.

Arogundade \& Bukola, B. (2011). Entrepreneurship education: An imperative for sustainable development in nigeria. Journal of Emerging Trends in Educational Research and Policy Studies (JETERAPS), 2, 1, pp.26-29.

Badan Pusat Statistik. (2013). Laporan bulanan data sosial ekonomi. Jakarta: Badan Pusat Statistik.

Borg, W.R. \& Gall, M.D. (1983). Educational research: An introduction. USA: Longman, Inc.

Cahyo. Pengangguran lulusan SMA-SMK masih tinggi. Diakses tanggal 30 September 2012 dari http://www.neraca.co.id/ 2011/11/07/pengangguran-lulusan-smasmk-masih-tinggi/.

Depdiknas. (2007). Konsep pengembangan model integrasi kurikulum pendidikan kecakapan hidup pendidikan menengah. Jakarta: Departemen Pendidikan Nasional Badan Penelitian dan Pengembangan Pusat Kurikulum.

Devi, P. K., Sofiraeni, R., \& Khairuddin. (2009). Pengembangan perangkat pembelajaran. Bandung: PPPPTK IPA.

Fitriani, A., Harnanik, \& Kusumantoro. (2012). Faktor-faktor yang mempengaruhi minat berwirausaha pada siswa kelas XII SMK Negeri 1 Kandeman Kabupaten Batang tahun 2011/2012. Economic Education Analysis Journal, 1, 2, pp.1-5.

Fu'adi, I. F., Eko, B., \& Murdani. (2009). Hubungan minat berwirausaha dengan prestasi praktik kerja industri siswa kelas XII Teknik Otomotif SMK Negeri 1 Adiwerna Kabupaten Tegal tahun ajaran 2008/2009. Jurnal PTM, 9, 2, pp.92-98.

Gorman, G., Hanlon, D., \& King, W. (1997). Some research perspectives on entrepreneurship education, enterprise education, and education for small business management: A ten year literature review. International Small Business Journal, pp.56-77.

Hakim, A. (2010). Model pengembangan kewirausahaan sekolah menengah kejuruan (SMK) dalam menciptakan kemandirian sekolah. Riptek, 4, 1, pp.1-14.

Hosseini, S., \& Ahmadi, A. (2012). The study of effect entrepreneurship education programs based on swot model in technical college, American Journal of Scientific Research, 69, pp.143-150.

Kemdiknas. (2010). Modul 2 konsep dasar kewirausahaan. Jakarta: Direktorat Pembinaan Khusus dan Kelembagaan Direktorat Jenderal Pendidikan Non Formal dan Informal Kementerian Pendidikan Nasional.

Kemdiknas. (2010). Petunjuk teknis program pendidikan kewirausahaan masyarakat melalui kursus dan pelatihan. Jakarta: Kementerian Pendidikan Nasional Direktorat Jenderal Pendidikan Nonformal dan Informal Direktorat Pembinaan Kursus dan Kelembagaan.

Kemdiknas. (2010). Pengembangan kewirausahaan: Bahan pelatihan penguatan metodologi pembelajaran berdasarkan nilainilai budaya untuk membentuk daya saing dan karakter bangsa. Jakarta: Kementerian Pendidikan Nasional Badan Penelitian dan Pengembangan Pusat Kurikulum.

Khoiri, N. (2011). Pengembangan perangkat pembelajaran fisika berbasis life skill untuk meningkatkan minat kewirausahaan siswa. Jurnal Pendidikan Fisika Indonesia, 7, pp.84-88.

Kuratko, D.F. \& Hodgetts, R.M. (2004). Entrepreneurship: Theory, process. practice. Mason, OH: South-Western Publishers.

Kusuma, E., \& Siadi, K. (2010). Pengembangan bahan ajar kimia berorientasi chemoentrepreneurship untuk meningkatkan hasil belajar dan life skill mahasiswa. 
Jurnal Inovasi Pendidikan Kimia, 4, 1, pp.544-551.

Lulusan SMK diharapkan ciptakan pekerjaan. (2010, 23 November). Kompas. Diambil pada tanggal 30 September 2012, dari http://edukasi.kompas.com/read/2010/1 1/23/12002370/Lulus.SMK.Diharapkan. Ciptakan.Pekerjaan.

Nurohman, S. (2006). Penerapan pendekatan sains-teknolohi-masyarakat dalam pembelajaran IPA sebagai upaya peningkatan life skills peserta didik. Majalah Ilmiah Pembelajaran, 2, 1, pp.59-71.

Nuryanti, B.L., \& Mahri, A.J.W. (2010). Model pendidikan pengembangan kecakapan hidup berlandaskan jiwa kewirausahaan. Proceedings of The 4th International Conference on Teacher Education; Join Conference UPI \& UPSI Bandung, Indonesia, pp.801-824.

Rohaeti, E., Widjajanti, E.LFX., \& Padmaningrum, R.T. (2009). Pengembangan lembar kerja siswa (LKS) mata pelajaran sains kimia untuk SMP. Inovasi Pendidikan, 10, 1, pp.1-11.

Sudira, P. (2006). Kurikulum tingkat satuan pendidikan SMK. Jakarta: Departemen Pendidikan Nasional Direktorat Jenderal Manajemen Pendidikan Dasar dan Menengah Direktorat Pembinaan Sekolah Menengah Kejuruan Subdit Pembelajaran.

Sugiyono. (1997). Metode penelitian administrasi. Bandung: Alfabeta.

Sugiyono. (2007). Metode penelitian kuantitatif kualitatif dan $R \& D$. Bandung: Alfabeta.

Suharti, L., \& Sirine, H. (2011). Faktor-faktor yang berpengaruh terhadap niat kewirausahaan (entrepreneurial intention): Studi terhadap mahasiswa Universitas Kristen Satya Wacana, Salatiga. Jurnal Manajemen dan Kewirausahaan, 13, 2, pp.124-134.
Suryana. (2004). Modul 1 kewirausahaan SMK: Memahami karakteristik kewirausahaan. Jakarta: Direktorat Pendidikan Menengah Kejuruan Direktorat Pendidikan Dasar dan Menengah Departemen Pendidikan Nasional.

USAID DBE 3. (2009). Pengajaran profesional dan pembelajaran bermakna 3 modul pelatihan. USAID DBE 3 Relevant Education for Youth.

Utami, Y.G.D., \& Hudaniah. (2013). Self efficacy dengan kesiapan kerja siswa sekolah menengah kejuruan. Jurnal Ilmiah Psikologi Terapan, 01, 01, pp.39-51.

World Health Organization (WHO). (1997). Life skills education for children and adolescents in schools: Introduction and guidelines to facilitate the development and implementation of life skills programmes. Geneva: WHO Programme on Mental Health

Wibowo, M. (2011). Pembelajaran kewirausahaan dan minat wirausaha lulusan smk. Eksplanasi, 6, 2, pp.109-122.

Widjajanti, E.LFX. (2008, Agustus). Kualitas lembar kerja siswa. Makalah disajikan dalam Kegiatan Pengabdian Masyarakat dengan judul "Pelatihan Penyusunan LKS Mata Pelajaran Kimia Berdasarkan Kurikulum Tingkat Satuan Pendidikan Bagi Guru SMK/MAK, di Universitas Negeri Yogyakarta.

Wiratno, S. (2008). Kajian kebijakan pendidikan kecakapan hidup (life skill) pada sekolah menengah pertama. Jurnal Pendidikan dan Kebudayaan, 072, 14, pp.507-531.

Zampetakis, L. A., Gotsi, M., Andriopoulos, C.; \& Moustakis, V. (2011). Creativity and entrepreneurial intention in young people: Empirical insights from business school students. Entrepreneurship And Innovation, 12, 3, 189-199. 